\title{
IMPACT OF PERCEIVED RISK AND TRUST ON ONLINE SHOPPING BEHAVIOUR: A STUDY FROM INDIAN PERSPECTIVE
}

\author{
Ruhani Bahl \\ Research Scholar, School of Management Studies, \\ IGNOU, New Delhi, India \\ Dr. Subodh Kesharwani \\ Associate Professor, School of Management Studies, \\ IGNOU, New Delhi, India
}

\begin{abstract}
E-commerce has been quite a popular and most talked about thing in these days, especially during Covid times in India. Consumers have got equipped and are now familiar on buying products online across different age groups given the current circumstances where staying home is the way to be protected against corona virus. This change in consumer behaviour is supported in a report published by Statista Research Department, in 2020, there were roughly 160 million online customers every year, contrasted with around 135 million online customers in 2019 in India. According to the previous studies, Perceived Risk and Trust are the two major variables that affect consumers' behaviour while shopping online in addition to the other variables. The objective and purpose of this paper is to understand and evaluate the impact of perceived risk and trust on the online buying behaviour from Indian perspective. This paper is based on the outcome of a primary online survey and Structural equation modelling technique was applied to test the hypothesis. As per the analysis, it could be concluded that Perceived Risk has a negative influence on Trust and Online Shopping Behaviour. Also, Trust has a positive influence on Online Shopping Behaviour.
\end{abstract}

Key words: Online Shopping Behaviour, Perceived Risk, Trust, Buying Behaviour, Ecommerce, Covid Impact

Cite this Article: Ruhani Bahl and Subodh Kesharwani, Impact of Perceived Risk and Trust on Online Shopping Behaviour: A Study from Indian Perspective, International Journal of Management, 11(12), 2020, pp 3549-3567.

https://iaeme.com/Home/issue/IJM?Volume $=11 \&$ Issue $=12$ 


\section{INTRODUCTION}

With more than 560 million web Users, in the world India is the second biggest online market, positioned after China. It was assessed that by 2023 , there would be more than 650 million web Users across the nation. Notwithstanding the huge base of web Users, the web penetration rate in the nation remained at around 50\% in 2020. This implied that around half of the 1.37 billion Indians had access to the web that year. There has been a steady expansion in internet accessibility contrasted with only five years prior, when the web penetration rate was around 27 percent.

According to report published by Statista Research Department, In 2020, there were roughly 160 million online customers every year, contrasted with around 135 million online customers in 2019 in India. This expansion can be credited to the development of the online business industry in India and to the (COVID-19) pandemic, which prompted an adjustment in the shopping conduct of the customers.

In retail area, one of the significant variables which impacts shopper online conduct is the demographics factors (Park and Jun, 2003). Fathima (2015) examined that most of the customers bought online in India because of ease of procurement, wide range of cost, brand expansion alongside the rebate advantage. El-Ansary (2013) clarified that trust, eadministration quality, attitude towards internet shopping and shoppers' demographic are the factors which influence web based shopping behaviour of customers.

E-commerce in Indian markets is growing up at a really fast speed. Frequently recognized in those examinations, and specifically noteworthy to our research, is the impact of customers' view of risk and trust when thinking about buying on the web and online. Studies keep on distinguishing that risk and trust factors are significant and should be tended to (Wu et al., 2010; McCole et al., 2010).

Today these fundamental drivers of internet business remain and incorporate the thought of building trust while dealing with the perceived risk of procurement (Bolton et al., 2008; Biswas and Burman, 2009; Schlosser et al., 2006; Bu“ttner and Go“ritz, 2008).

As per the literature on online purchase behaviour, risk perceived is seen as very significant, however the examination and studies has been restricted to a couple of item classifications, making speculations and generalizations about its effect hard to decide (Miyazaki and Fernandez, 2000). These examinations recommend that the higher the risk the more uncertain items and less items are to be bought on the web (Doolin et al., 2005; Jarvenpaa et al., 1999). By and large, it tends to be seen that perceived risk has been widely utilized in investigations taking a look at both offline and online buying behaviour and in an assortment of item classes. In light of the above examples, the paper considers perceived risk as an adaptable construct that is material to numerous zones.

Bilgihan (2016) uncovered this reality in his examination and study that there is the imperative effect of trust in client's dedication and loyalty in web based or online shopping. Trust is the main precursor of e-loyalty for youthful clients. They stay faithful to the brands that they trust. The consequences of Kim et al. (2012) uncovered that perceived trust applied a preferred impact over perceived price on buying aims intentions for both potential and repeated clients of an online store. Metropolitan et al. (2009) gave a general design of how online trust functions. The site influences trust which thus alters client purchasing behaviour that lead to retailer's deals and benefit achievement. Clients gain from their purchasing experience and item use.

For the purpose of this study, we take into consideration three constructs i.e. Trust, Perceived Risk and Online Shopping Behaviour and evaluated their effect on each other from Indian perspective especially during the Covid times. The objective of this study is to 
understand and 1) Examine how Perceived Risk influence Trust 2) To examine how Indian customers' risk perception and trust impact online shopping behaviour.

\section{LITERATURE REVIEW}

\subsection{Trust}

Trust is as often recognized as "confidence" in another person or institute (Venkatesan, 1968; Shimp and Bearden, 1980). Trust is viewed as one of the central points of problems the purchaser thinks about when settling on a choice to buy. Trust, as risk perceived, can be viewed as an adaptable variable relevant in different controls and disciplines (Morgan and Hunt, 1994). Trust is characterized as the essential assumption an individual has on the unwavering quality of the co-exchanger's guarantees (Rotter, 1967). Likewise, trust can be deciphered as the result of the integrity and reliability of the merchant, like quality assessment measures like trustworthiness and obligation (Dwyer and Lagace, 1986). Morgan and Hunt (1994) verify this point of view by conceptualizing trust as the structure of faith in the integrity and reliability of the merchant. In doing as such, Doney and Cannon (1997) considered trust as the space of a strong validity between the purchaser and the merchant, and the dependability of the merchant's guarantees. This view was likewise upheld by Gao et al. (2002) who deciphered trust as the unwavering quality and trustworthiness perceived by the co-exchangers. Trust is considered as the fundamental essential component in web based exchanging (Gao et al., 2002). Brannigan and De Jager (2003) characterized trust in online exchanges as the mix of trust in online exchange and trust in the online dealer. It very well may be contended that by concentrating on the buying viewpoint, these two sorts of trust address one basic topic; the trust to buy on the web (Ba, 2001). Also, trust in web based buying is frequently deciphered as the guarantee and confirmation of online venders to convey excellent items or administrations to online purchasers (Cowcher, 2001). It very well may be considered from these examples that the confirmations of online venders is a fundamental component to a purchaser's trust to buy on the web.

Buyers would possibly take part in any online business in the event that they could communicate some degree of trust in the deal and the merchant or dealer. Rempel et al. (1985, p.96) characterized trust as the sensations of certainty and security in the mindful reaction of the other party. Sohaib \& Kang (2015) called this trust in their work as iTrust (relational Trust), that is the certainty one gathering hosts in the other get-together. In web based business, the parties included are online purchaser furthermore, the online seller (Tan and Sutherland, 2004). Johnson and Grayson (2005) isolated trust into affect-base and cognitive. Cognitive based trust radiates from arrangement of reasonable reasoning, and accordingly shows the customer's certainty that an online retailer is straightforward, exact and reliable and also, keeps guarantees (Punyatoya, 2019; Brengman and Karimov, 2012; Johnson and Grayson, 2005). Affect-based trust, otherwise called enthusiastic and emotional trust radiates from customer's instinct, senses, or sentiments concerning whether an individual, gathering or association is reliable (Brengman and Karimov, 2012; Johnson and Grayson, 2005; Kramer, 1999). Kramer (1999) is of the view that trust is an unpredictable state that comes from person's deficient information about the thought processes of the other party in a relationship. On account of web based business, trust isn't just about the trader, however even the online platform as well (Bianchi and Andrews, 2012; Harridge-March, 2006).

\subsection{Perceived Risk}

While purchasers will in general see some risk in buying offline, they are probably going to perceive more risk with web-based buying online (Doolin et al., 2005). It is proposed that this risk in an online exchange may result from a purchaser's failure to review and look at an item's 
quality for themselves (Tan, 1999), and from giving and bargaining individual data (Doolin et al., 2005; Liebermann and Stashevsky, 2002). Perceived risk related with web-based buying got less consideration in early internet buying literature (Jarvenpaa and Todd, 1997). A few researchers (Pires et al., 2004) noticed that risk perceived towards internet buying has been dismissed in purchaser conduct research. This is maybe in light of the fact that the significance of perceived risk to online buying was not clear around then. To date it is clear that a purchaser's perceived risk is one of the significant obstructions to the development of online trade (Awad, 2004; Culnan, 1999; FTC, 2000; United Nations, 2001, 2005), there have been various examinations tending to this issue.

Miyazaki and Fernandez (2001) characterized online risk perceived as the risks identified with shopper's online experience, and buyer's stress over the security and privacy issues when managing on the web exchanges. Risk perceived is viewed as a crucial idea in shopper conduct examination, the target of such investigation is frequently to distinguish intends to decrease the risk. Characterizing and clarifying the perceived risk is fundamental for comprehension of how a specific buy choice is taken, giving promoting experts the data expected to encourage the culmination of the exchange. Literatures related to Marketing states that risk perceived can be investigated as far as vulnerability and anticipated outcomes (Cox 1967, Jacoby and Kaplan 1972). The examination of the normal results was centered around the possibility of "misfortune or loss" (Cox 1967), yet subsequent investigations have prompted the coordinated idea that alludes to the likelihood of risk and its significance.

The literature available on Marketing provides different dimensions of risk perceived as below:

Table1: Types of Perceived Risk in context of Online Shopping

\begin{tabular}{|c|l|l|}
\hline Sr. No. & Risks & Researchers \& Years \\
\hline 1 & Financial Risk & Kaplan (1974), Szybillo and Jacoby (1993), Michel Laroche (2004) \\
\hline 2 & $\begin{array}{l}\text { Performance } \\
\text { Risk }\end{array}$ & $\begin{array}{l}\text { Kaplan (1974), Fatma A. Mohamed (2011), Szybillo and Jacoby } \\
\text { (1993), Michel Laroche (2004) }\end{array}$ \\
\hline 3 & Physical Risk & Kaplan (1974), Szybillo and Jacoby (1993), Michel Laroche (2004) \\
\hline 4 & Social Risk & $\begin{array}{l}\text { Kaplan (1974), Fatma A. Mohamed (2011), Szybillo and Jacoby } \\
\text { (1993), Michel Laroche (2004) }\end{array}$ \\
\hline 5 & $\begin{array}{l}\text { Convenience/ } \\
\text { time Risk }\end{array}$ & $\begin{array}{l}\text { Kaplan (1974), Roselius 1971, Fatma A. Mohamed (2011), Michel } \\
\text { Laroche (2004) }\end{array}$ \\
\hline 7 & $\begin{array}{l}\text { Psychological } \\
\text { Risk }\end{array}$ & $\begin{array}{l}\text { Kaplan (1974), Szybillo and Jacoby (1993), Mitchell and Greatorex } \\
\text { (1993), Fatma A. Mohamed (2011), Michel Laroche (2004) }\end{array}$ \\
\hline 8 & Privacy Risk & Kaplan (1974) \\
\hline
\end{tabular}

Literature available on Marketing considers two different ways for examining the risk perceived: one in which risk perceived is for sure a multidimensional variable, and the second, wherein each kind of risk is evaluated separately, with its particular significance. Notwithstanding, the commitment of every part in gathering the risk variable changes for every person and from one purchasing interaction to another (Pope et al., 1999).

As per specialists in the field, perceived risk in web-based shopping is one of the components that impact customers' choice to get involved or not the in online business. Thus, the accomplishment of an online shop is in exacting connection with how it figures out that 
how to make in the psyche of the buyer the impression of lower risk. A specific level of risk is found in any purchasing interaction, regardless of whether it happens on the web or offline. Online shopping is viewed as more unsafe than customary purchasing, and furthermore an online buy includes more serious risk than an offline exchange.

\subsection{Online Shopping Behaviour}

Customer behaviour is characterized by Walters $(1974$, p.7) as the cycle whereby people choose whether, where, how, what, when, where, how, and from whom to buy products and services. Schiffman and Kanuk (1997, p.648) additionally characterized shopper's behaviour as the conduct that customers show in looking for, buying, utilizing, assessing, and discarding items, services, and thoughts. Client's (individual or corporate) attitude towards the buy, use and assessment of online shipper, online platform, products and enterprises, when making exchange utilizing web and internet.

Online shopping behaviour (known as online purchase behaviour and Internet shopping/purchasing behaviour) alludes to the way items and services are bought items via the Internet. Online shopping behaviour refer to the process of buying items or products and services online ( $\mathrm{Li}$ and Zhang, 2002).

Risks related to online purchase and the impact on online shoppers behaviour have been generally explored and researched (D'Alessandro et al., 2012; Mousavizadeh et al., 2016; Pappas, 2016; Doolin et al., 2005). It fundamentally includes the environment required for shoppers to be certain about the innovation and technology or stage utilized looking out, buying and making installments on the web (Bianchi and Andrews, 2012; McCole et al., 2010). An ordinary internet business may require client's data like location, telephone number, email, or potentially monetary details, and these may introduce some risk perceived with respect to the client (Tsiames and Siomkos, 2003; Chen et al., 2017; Liebermann and Stashevsky, 2002; Doolin et al., 2005). Harridge-March (2006) introduced that web based shopping puts purchasers helpless before an obscure exchanging and trading partner, who has the chance to misuse the client for parochial interest. This makes buyers careful about the validity of the business data put on the web, deals recommendation and item quality (Chaudhuri and Holbrook, 2001). Since shoppers can't make practical evaluation of item quality before buy, new items brands are related with high perceived online risk (Tan, 1999; Mitchell, 1998).

\subsection{Online Shopping Behaviour and Risk}

The environment online implies absence of control by the customer that is compelled to cooperate with mysterious and unknown speakers who may exploit him. In this way, it may be said that, on account of internet shopping, the risks are higher and they are explicit to the environment - like the risk of misrepresentation and fraud through burglary and theft of individual information. The particular attributes of perceived risk in web based shopping come from the highlights that the Internet has another innovation and technology. Accordingly, perceived risk is in very close relationship with the buyer's impression of the Internet as a shopping channel (Bhatnagar et al., 2000). For instance, buyers frequently accept that in the event that they complete the request form on the Internet their card details are presented to extortion and fraud (Bhatnagar et al., 2000, Jarvenpaa and Todd, 1997). Hence, it will be interesting to evaluate this relationship from Indian perspective.

\subsection{Online Shopping Behaviour and Trust}

Studying trust without risk consideration is viewed as incomplete and deficient (Lee and Turban, 2001). Viklund (2003) for instance discovered trust to strongly affect risk perceived. That is, more elevated and igher level of trust decreases the impact risk perceived has on 
customer behaviour like online buys. Studies like Eastlick et al. (2006) have additionally introduced a negative connection between risk perceived and trust. Along these lines, decreased perceived risk builds trust and great attitude towards web based shopping (Black, 2005; Van der Heijden et al., 2003). The correct harmony between risk perceived and trust is important for the success of web based business (Grabner-Krauter and Kaluscha, 2003).

\subsection{Proposed Model \& Hypothesis:}

For the purpose of this study, the model proposed below forms the basis of the research. The objective of the study is to find out the influence and impact of two variables, Trust and Risk, on Online Shopping Behaviour in India (Delhi NCR Region)

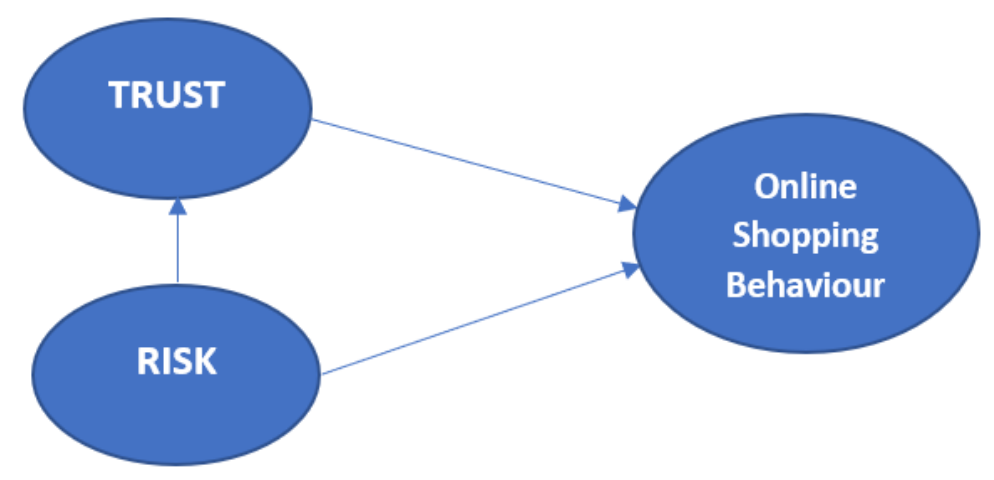

Fig 1: Proposed Model for understanding the impact of Risk \& Trust on Online Shopping Behaviour

Risk Perceived and trust have impact on one another and on online buys. Trust is negatively impacted with perceived risk (Kimery and McCord, 2002; Eastlick et al., 2006). Higher trust probably diminishes risk perceived. For instance, Jarvenpaa et al. (1999) propose that greater trust in the online dealers reduces risk perceived, and this decreased risk perceived expands the purchaser's readiness to buy on the web. Essentially, van der Heijden et al. (2003) report that decresed risk perceived builds trust and has postive outcome on web based buying i.e. Online Shopping

Meaningful discoveries propose that risk perceptions about utilizing the Web for buying can exceed a shopper's insights about the advantages and at the same time is considered as an essential hindrance to doing so (Kuhlmeier and Knight, 2005; Bhatnagar and Ghose, 2004; Yang and Jun, 2002; Andrews and Boyle, 2008). In addition, in any event, when people do buy on the web, they are as yet careful about the risk engaged with the Online environment (Forsythe et al., 2006, Andrews and Boyle, 2008). Hence, the first hypothesis proposed is as below:

\section{H1: Perceived risk has a negative impact on trust}

The likelihood or purchase intention is negatively influenced by the Perceived risk online (Yeung and Morris, 2006; Vijayasarathy and Jones, 2000). Online buying decision is also affected by it as well as the quantity of web-based purchase (Dillon and Reif, 2004; Miyazaki and Fernandez, 2001; Doolin et al., 2005). Consistently, it's been identifies that perceived risk have a negative impact on online purchase behaviour (Kim et al., 2008). Hence, the second proposed hypothesis is: 


\section{H2: Perceived risk has a negative impact on the online shopping behaviour}

Trust has positive impact and influence on online purchase behaviour (Ha and Stoel, 2009; Pavlou and Fygenson, 2006; McCole et al., 2010).

There also exists a positive relationship between online purchase intention and trust as per the studies on trust (Koufaris and Hampton-Sosa, 2002; Eastlick et al., 2006; Shim et al., 2004; Gefen,2000)

Online buys and purchased are positively influenced by Trust (Punyatoya, 2019; Li et al., 2014; Pappas,2016; Urban et al., 2009; McCole et al., 2010). Thus, the final hypothesis:

\section{H3: Trust has a positive impact on the online buying behaviour}

Table 2: Items in the survey

\begin{tabular}{|c|c|c|}
\hline Scale & Item & References \\
\hline \multirow{4}{*}{ Trust } & The online retailers are trustworthy. & Pavlou \\
\hline & The online retailers keep their promises and commitments. & -2003 \\
\hline & The online retailers keep their customer's best interests in mind & \\
\hline & Products sold by the online retailers are in accordance with the reviews written online & \\
\hline \multirow{7}{*}{ Risk } & Shopping online is risky. & Schlosser \\
\hline & Providing credit card information online is risky. & et al. 2006 \\
\hline & Providing personal information (i.e., social security number and mother's maiden name) online is risky. & \\
\hline & Purchasing items online is risky. & \\
\hline & Providing my and phone number online is risky. & \\
\hline & Registering online is risky. & \\
\hline & It is riskier to shop online for a product than to shop offline for it. & \\
\hline \multirow{4}{*}{ Online Shopping Behaviour } & I make purchases online through from internet websites & $\operatorname{Lim}(2001)$ \\
\hline & I use online websites or applications to make purchases & , Abdullah Osman (2015) \\
\hline & I buy different products online & \\
\hline & I have made purchases online in the past & \\
\hline
\end{tabular}

\section{METHODOLOGY}

Survey Details: The questionnaire was developed from the adaptation of the scales presented in various studies and was floated online. The survey is divided into the $\mathbf{3}$ sections: Demographic Details, General Purchase Preferences, and Specific Questions for all variables in the last section.

A filtering question was used to find out if each respondent uses internet for making purchases online

Three variables were used in this research study that were perceived risk, trust and online shopping behaviour. The items were adapted from different scales and supported by existing studies. Perceived risk is measured by 7 items that were adapted from Schlosser et al. (2006), Trust is measured by 4 items adapted from Pavlou (2003), and Online Shopping is measured by 4 variables adapted from Yi Jin Lim, Abdullah Osman (2015). All items were measured on likert scales of 7 points ( $1=$ Strongly disagree; $7=$ Strongly agree $)$ which were extensively used on previous studies on making purchases online.

Survey Participants and Sampling: For the purpose of this study, the population is considered as any person aged between 16-75 years of age, who has access to the web or internet and uses that for making any buy or purchases online. Also, the individual should be residing in India's Tier 1 cities mainly in Delhi NCR Region.

Sampling: Convenience sampling technique is used for data collection. Also, collected data should be a minimum of 10 multiplied by measurement variables numbers (statements in your survey) based on the rule of thumb for sample size where SEM is used for analyzing data. Thus, a minimum of 150 sample size is determined. However, since SEM will be applied using AMOS, a minimum of 200 of sample is required. 
Analysis Tools: For descriptive analysis and calculating Cronbach alpha, SPSS was used. For validating measurement model and evaluating structural model, AMOS was used.

A total of 225 responses were received out of which 15 respondents responded that they do not shop online and were removed from the data collected. Further, a total of 210 responses were considered for analysis

\subsection{Analysis}

\section{Descriptive Analysis}

The total no. of respondents whose responses are considered are 210 responses. Below are some of the response distribution:

Distribution by demographics:

By Gender:
\begin{tabular}{|l|c|}
\hline Options & Percentage \\
\hline Male & $36 \%$ \\
\hline Female & $64 \%$ \\
\hline Others & $0 \%$ \\
\hline
\end{tabular}

By Occupation:

By Age:

\begin{tabular}{|l|c|}
\hline Options & Percentage \\
\hline $10-20$ Years & $19 \%$ \\
\hline $20-30$ Years & $50 \%$ \\
\hline $30-40$ Years & $14 \%$ \\
\hline $40-50$ Years & $7 \%$ \\
\hline Above 50 Years & $10 \%$ \\
\hline
\end{tabular}

\begin{tabular}{|l|c|}
\hline Options & Percentage \\
\hline Employed & $54 \%$ \\
\hline Self-employed & $12 \%$ \\
\hline Unemployed & $4 \%$ \\
\hline Student & $23 \%$ \\
\hline Retired & $6 \%$ \\
\hline
\end{tabular}

\section{By Income:}

\begin{tabular}{|l|c|}
\hline Options & Percentage \\
\hline Up to 5 lakhs p.a. & $36 \%$ \\
\hline 5 lakhs - 10 lakhs p.a. & $22 \%$ \\
\hline 10 lakhs - 15 lakhs p.a. & $20 \%$ \\
\hline 15 lakhs - 20 lakhs p.a. & $10 \%$ \\
\hline Above 20 lakhs p.a. & $12 \%$ \\
\hline
\end{tabular}

Distribution by buying preferences:

Preferred sites for shopping online:

\begin{tabular}{|l|c|}
\hline Options & Percentage \\
\hline Flipkart & $42 \%$ \\
\hline Amazon & $92 \%$ \\
\hline Snapdeal & $10 \%$ \\
\hline Jabong & $3 \%$ \\
\hline Myntra & $52 \%$ \\
\hline Homeshop 18 & $3 \%$ \\
\hline Shopclues & $2 \%$ \\
\hline Firstcry & $5 \%$ \\
\hline Nykaa & $35 \%$ \\
\hline Other & $8 \%$ \\
\hline
\end{tabular}


Type of Products bought online:

\begin{tabular}{|l|c|}
\hline Options & Percentage \\
\hline Fashion (clothes, handbags etc.) & $82 \%$ \\
\hline Electronics \& software & $49 \%$ \\
\hline Books, music, films, etc. & $37 \%$ \\
\hline Mobile Phones & $42 \%$ \\
\hline Health care/Pharmaceutical products & $22 \%$ \\
\hline Travel & $20 \%$ \\
\hline Home and Garden & $18 \%$ \\
\hline Sports & $15 \%$ \\
\hline Motors (cars, equipment, etc.) & $3 \%$ \\
\hline Groceries & $51 \%$ \\
\hline Cosmetic products & $48 \%$ \\
\hline Other & $2 \%$ \\
\hline
\end{tabular}

\subsection{Reliability}

For the purpose of calculating Cronbach Alpha to check the internal consistency within constructs items, we used SPSS 20. According to the standard norms, all the variables' Cronbach Alpha are above 0.7 proving that there is internal consistency for these variables. As stated before, the $\mathrm{N}$ i.e. no. of responses is 210 .

\begin{tabular}{|l|c|c|}
\hline Variable & Cronbach's Alpha & N of Items \\
\hline Overall & 0.722 & 15 \\
\hline Trust & 0.882 & 4 \\
\hline Risk & 0.931 & 7 \\
\hline $\begin{array}{l}\text { OSP (Online Shopping } \\
\text { Behaviour) }\end{array}$ & 0.865 & 4 \\
\hline
\end{tabular}

After calculating the reliability, AMOS 24 statistical tool was used in order to apply and measure the results of Measurement model (CFA) and Structural Model (SEM). For calculating the validity of the constructs, CFA was used. Below is the model along with the results indicated in the tables:

\subsection{Measurement Model}

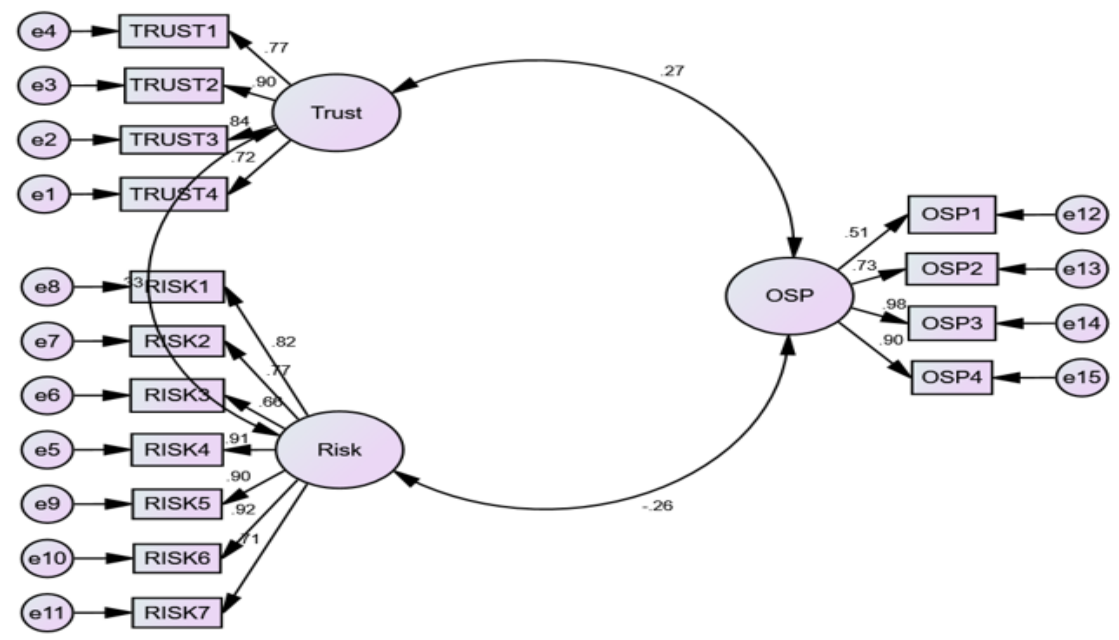

Figure 2 Measurement Model for Risk, Trust and Online Shopping Behaviour

Note: OSP indicates Online Shopping Behaviour 
Regression Results indicate that the $\mathrm{P}$ value is less than $<0.05$ and hence, is significant. It holds true for all items. Refer to the table below for details:

\begin{tabular}{|c|c|c|c|c|c|c|}
\hline & & & Estimate & S.E. & C.R. & $\mathrm{P}$ \\
\hline TRUST4 & $<-$ & TRUST & 1 & & & \\
\hline TRUST3 & $<--$ & TRUST & 1.151 & 0.099 & 11.625 & $* * *$ \\
\hline TRUST2 & $<--$ & TRUST & 1.185 & 0.097 & 12.249 & $* * *$ \\
\hline TRUST1 & $<-$ & TRUST & 1.057 & 0.099 & 10.698 & $* * *$ \\
\hline RISK4 & $<--$ & RISK & 1 & & & \\
\hline RISK3 & $<--$ & RISK & 0.762 & 0.067 & 11.381 & $* * *$ \\
\hline RISK2 & $<--$ & RISK & 0.858 & 0.059 & 14.629 & $* * *$ \\
\hline RISK1 & $<--$ & RISK & 0.771 & 0.046 & 16.589 & $* * *$ \\
\hline RISK5 & $<-$ & RISK & 1.077 & 0.052 & 20.685 & $* * *$ \\
\hline RISK6 & $<-$ & RISK & 1.07 & 0.049 & 21.927 & $* * *$ \\
\hline RISK7 & $<--$ & RISK & 0.796 & 0.063 & 12.74 & $* * *$ \\
\hline OSP1 & $<--$ & OSP & 1 & & & \\
\hline OSP2 & $<--$ & OSP & 1.309 & 0.177 & 7.385 & $* * *$ \\
\hline OSP3 & $<-$ & OSP & 1.479 & 0.18 & 8.222 & $* * *$ \\
\hline OSP4 & $<-$ & OSP & 1.291 & 0.159 & 8.099 & $* * *$ \\
\hline
\end{tabular}

Assessing the Construct Validity through Convergent and Discriminant Validity, we used professor's gaskin's plug in (Gaskin, J., James, M., and Lim, J. (2019), "Master Validity Tool", AMOS Plugin. Gaskination's StatWiki.) and the following results were achieved:

\subsection{Convergent Validity}

\section{Model Validity Measures}

Validity Analysis

\begin{tabular}{|c|c|c|c|c|c|c|c|}
\hline & CR & AVE & MSV & MaxR(H) & TRUST & RISK & OSP \\
\hline TRUST & 0.885 & 0.659 & 0.109 & 0.903 & $\mathbf{0 . 8 1 2}$ & & \\
\hline RISK & 0.933 & 0.668 & 0.109 & 0.952 & $-0.330^{* * *}$ & $\mathbf{0 . 8 1 7}$ & $\begin{array}{c}- \\
0.262^{* *}\end{array}$ \\
\hline OSP & 0.872 & 0.642 & 0.074 & 0.972 & 0.273 & $*^{* *}$ & $\mathbf{0 . 8 0 1}$ \\
\hline
\end{tabular}

Validity Concerns

*** Correlation is not specified in the model.

No validity concerns here.

For all the constructs/variables, Convergent Validity was achieved as AVE $>0.5, \mathrm{CR}>0.7$ and $\mathrm{CR}>\mathrm{AVE}$.

\subsection{Discriminant Validity}

For all the variables, Discriminant Validity was achieved as:

- Square roots of AVE should be higher than the other correlation coefficients for adequate discriminant validity (Fornell and Larcker, 1981), OR

- $\quad$ HTMT value should be below 0.9 
HTMT Analysis

\begin{tabular}{|c|c|c|c|}
\hline & TRUST & RISK & OSP \\
\hline TRUST & & & \\
\hline RISK & 0.331 & & \\
\hline OSP & 0.299 & 0.22 & \\
\hline
\end{tabular}

HTMT Warnings

There are no warnings for this HTMT analysis.

Model Fit Indices for Measurement Model: The indices show relatively good fit for the model.

\begin{tabular}{|l|l|l|l|}
\hline Model Fit Indices & Default Model & Recommended Criteria & Reference \\
\hline CMIN/DF & 3.922 & $<5$ & (Marsh \& Hocevar, 1985). \\
\hline CFI & 0.902 & $>0.9$ & $\begin{array}{l}\text { Bentler, 1990; Cole, 1987; Marsh, } \\
\text { Balla \& McDonald, 1988 }\end{array}$ \\
\hline NFI & 0.865 & $>0.8$ & $\begin{array}{l}\text { Bentler, 1990; Cole, 1987; Marsh, } \\
\text { Balla \& McDonald, 1988 }\end{array}$ \\
\hline RMSEA & & & $\begin{array}{l}\text { Bentler, 1990; Cole, 1987; Marsh, } \\
\text { Balla \& McDonald, 1988 }\end{array}$ \\
\hline
\end{tabular}

\subsection{SEM}

Further in the study, Structure Equation Modelling (SEM) in AMOS 24 is applied to test the model proposed and hypothesized paths. Below is the model along with the results indicated in the tables:

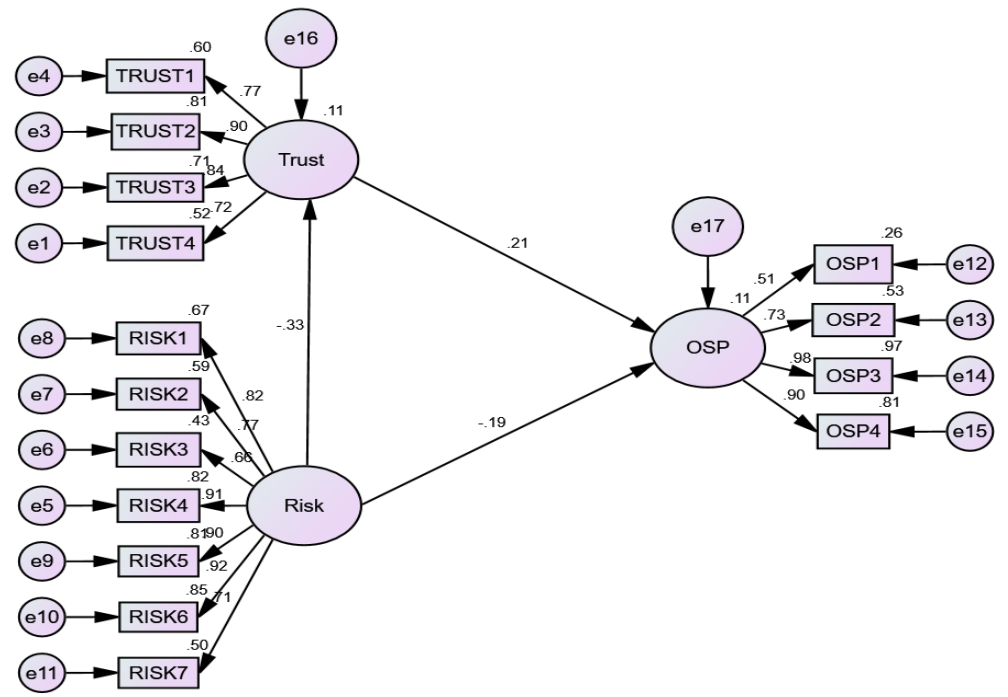

Figure 3 Structure Equation Model for Risk, Trust and Online Shopping Behaviour 
Model Fit Indices for Measurement Model: All Indices prove overall statistical fit and the model is acceptable

\begin{tabular}{|l|l|l|l|}
\hline Model Fit Indices & Default Model & Recommended Criteria & Reference \\
\hline CMIN/DF & 3.922 & $<5$ & (Marsh \& Hocevar, 1985) \\
\hline CFI & 0.902 & $>0.9$ & $\begin{array}{l}\text { Bentler, 1990; Cole, 1987; Marsh, } \\
\text { Balla \& McDonald, 1988 }\end{array}$ \\
\hline NFI & 0.865 & $>0.8$ & $\begin{array}{l}\text { Bentler, 1990; Cole, 1987; Marsh, } \\
\text { Balla \& McDonald, 1988 }\end{array}$ \\
\hline RMSEA & 0.074 & $<0.08$ & $\begin{array}{l}\text { Bentler, 1990; Cole, 1987; Marsh, } \\
\text { Balla \& McDonald, 1988 }\end{array}$ \\
\hline
\end{tabular}

\section{Hypothesis Testing}

Regression Weights: (Group number 1 - Default model)

\begin{tabular}{|lll|rrrr|}
\hline & & & Estimate & S.E. & C.R. & P \\
\hline TRUST & $<---$ & RISK & -0.233 & 0.053 & -4.391 & $* * *$ \\
OSP & $<--$ & TRUST & 0.161 & 0.062 & 2.608 & 0.009 \\
OSP & $<--$ & RISK & -0.105 & 0.042 & -2.52 & 0.012 \\
\hline
\end{tabular}

Standardized Regression Weights: (Group number 1 - Default model)

\begin{tabular}{|lll|r|}
\hline & & & Estimate \\
\hline TRUST & $<---$ & RISK & -0.33 \\
OSP & $<---$ & TRUST & 0.209 \\
OSP & $<--$ & RISK & -0.193 \\
\hline
\end{tabular}

Squared Multiple Correlations: (Group number 1 - Default model)

\begin{tabular}{|l|c|}
\hline & Estimate \\
\hline TRUST & 0.109 \\
OSP & 0.108 \\
\hline
\end{tabular}

The Hypothesis $\mathbf{1}$ is supported as results indicate that the relationship between Perceived Risk and Online Trust is significant and Perceived Risk is negatively related to Online Trust $(\beta=-0.33, P=* * *)$

The Hypothesis $\mathbf{2}$ is supported as results indicate that the relationship between Perceived Risk and Online Shopping Behaviour is significant and Perceived Risk is negatively related to Online Shopping Behaviour $(\beta=-0.193, P=0.012)$.

The Hypothesis 3 is supported as results indicate that the relationship between Online Trust and Online Shopping Behaviour is significant and Online Trust is positively related to Online Shopping Behaviour $(\beta=0.209, P=0.009$ ). 


\section{FINDINGS}

Past studies have indicated the Perceived Risk and Online Trust have inter dependency on each other Delgado-Ballester and Herna'ndez-Espallardo, 2008; van der Heijden et al., 2003. For trust, perceived risk is a necessity according to Kaluscha and Grabner-Krauter (2003). Study of trust is considered to be incomplete without consideration of risk according to Lee and Turban (2001). Perceived risk has a negative relationship with trust (Eastlick et al., 2006). Although the respondents who have taken our survey shop online, they still perceive the online environment to be risky which is quite consistent with the past researches (Ha and Coghill, 2008; Kuhlmeier and Knight, 2005; Bourlakis et al., 2008; McCole et al., 2010; Drennan et al., 2006).

Perceived Risk is considered to be one of the key barriers in the adoption of e-commerce and further has an effect on online shopping behaviour. The result observed in this study is found to be consistent with the studies conducted in the past like Featherman et al. (2010); Hong-Youl (2004) and Biswas and Biswas (2004). Although Perceived Risk has a significant impact on Online Shopping Behaviour, but the beta coefficient of Risk is lesser than that of Trust. It only indicates that Trust impacts Online Shopping Behaviour more strongly as compared to Perceived Risk.

Consumer's Trust in Online Shopping was expected to boost confidence of the consumers while shopping online in a country like India. It is supported by the studies that have taken place in the past like Li et al., 2014; Pappas, 2016; Urban et al., 2009, McCole et al., 2010. Trust is recognized as one of the most important factors that contribute to the success of e-commerce and influence shoppers' behaviour.

Out of the two factors that were considered in this study, Trust influences Online Shopping Behaviour as compared to the Risk. Thus, in the times of Corona, where the world (India as well) is moving towards adopting e-commerce and buying more items online, even though consumers are skeptical about the risk attached to the buying things online, the effect of perceived risk is not very high. It suggests that the benefits attached to buying items online outweighs and disadvantages as buying online offers advantages like convenience, minimal risk of virus, no human intervention while selecting products online, time saving, discount and offers etc. which are very important during covid times to the people across different generations.

Overall findings suggest that perceived risk and online trust have an impact on the consumer's behaviour towards online shopping for Indian Consumers, especially for people who belong to Delhi NCR region. Thus, e-commerce companies should take enough measures to make sure consumers feel secure and protected while shopping online and on web.

\section{IMPLICATIONS}

For mitigating risk and developing trust among consumers, e-companies can do the following:

A few investigations and research recommend that a decent method of decreasing the risk perceived is by expanding brand loyalty (Mitra, 1999; Bauer, 1967, Roselius, 1971). The brand implies a guarantee made by the organization to the customers, brand loyalty implies that this guarantee is satisfied. Subsequently, customers will get faithful to that brand, accordingly, the perceived risk is essentially diminished. Regardless of whether they see an item interestingly, customers will be affected by the brand since it gives validity and lessens the risk perceived (Mitra et al., 1999).

A compelling method to secure and protect the site (platform for e-shop) from unapproved access (breaking) is to set up a blend of models of authorization. Also, the association with an outsider confirmation or a third party assurance is critical as it signifies that the organization 
consents to safety efforts guaranteeing e-customer's privacy and security. In addition, an eorganizations and companies should offer to the clients the chance to survey its credibility. This point can be at first achieved by permitting tests and samples requesting as orders. Along these lines, clients can determine the nature of items, the exhibition of delivery, and the hour of delivery. Also, the believability of an e-organization/company is guaranteed by sending an email or sms that confirm exchange dispatch after every checkout interaction. Consumers could likewise feel that they have the control of their dispatched request, in case that they get useful messages during the course.

The above-mentioned measures would reinforce adoption of internet shopping, by causing e-customer to have a sense of security while he/she buys items online. Along these lines when any order is delivered with all the safety and precautions, the standing of e-business is expanded through the informal interaction. Accordingly, an organization benefits when consumers profits by a reasonable and common collaboration (Angeliki Vosa, 2014).

\section{LIMITATIONS \& FUTURE SCOPE}

Sample Size: The current population size is of 210 which is not good enough to generalize the results for India which is one of the countries to have largest population. Thus, a further research should be conducted by future researchers to if the findings are still valid and reliable

Lack of Specific Products: The study that was undertaken by keeping in mind various products like FMCG, Cosmetics, Apparels, Fashion etc. However, further studies should be conducted keeping in mind one product line

Lack of one specific e-commerce site: In the survey, it was asked if the respondent shops from various available e-commerce site. However, future research should be based upon assessing the risk and trust perceptions for a particular site, for ex., Amazon or Flipkart etc.

Limited variables considered: In this proposed model, other variables which are essential for and are pre-requisite for Online Shopping Behaviour are not considered, e.g., Attitude, Intention etc. Instead, the direct impact of Risk and Trust is evaluated directly on Online Shopping Behaviour. It will also be interesting to incorporate these variables and theories of consumer behaviour like TAM, TPB etc.

Role of Demographics: It will also be interesting to see how demographic variables could impact Online Shopping Behaviour differently. For example, how is it different by gender (Male Vs Female), Age groups (Across Generations), Income groups (Across different income groups) etc.

\section{REFERENCES}

[1] Andrews, L., \& Boyle, M. V. (2008). Consumers' accounts of perceived risk online and the influence of communication sources. Qualitative Market Research: An International Journal.

[2] Awad, E. M. (2004). Electronic commerce: From vision to fulfillment.

[3] Ba, S. (2001). Establishing online trust through a community responsibility system. Decision support systems, 31(3), 323-336.

[4] Bentler, P. M. (1990). Fit indexes, Lagrange multipliers, constraint changes and incomplete data in structural models. Multivariate Behavioral Research, 25(2), 163-172.

[5] Bertea, P. E. (2009). Perceived Risk and Online Shopping Behaviour-A Marketing Perspective. Available at SSRN 1521506.

[6] Bhatnagar, A., Misra, S., \& Rao, H. R. (2000). On risk, convenience, and Internet shopping behavior. Communications of the ACM, 43(11), 98-105. 
[7] Bilgihan, A. (2016). Gen Y customer loyalty in online shopping: An integrated model of trust, user experience and branding. Computers in Human Behavior, 61, 103-113.

[8] Bin Dost, M. K., Illyas, M., \& Abdul Rehman, C. (2015). Online shopping trends and its effects on consumer buying behavior: A case study of young generation of Pakistan. NG-Journal of Social Development, 417(3868), 1-22.

[9] Black, G. S. (2005). Predictors of consumer trust: likelihood to pay online. Marketing Intelligence \& Planning.

[10] Bolton, G., Loebbecke, C., \& Ockenfels, A. (2008). Does competition promote trust and trustworthiness in online trading? An experimental study. Journal of Management Information Systems, 25(2), 145-170.

[11] Bourlakis, M., Papagiannidis, S., \& Fox, H. (2008). E-consumer behaviour: Past, present and future trajectories of an evolving retail revolution. International Journal of E-Business Research (IJEBR), 4(3), 64-76.

[12] Brannigan, C. and De Jager, P. (2003), "Building e-trust", Computerworld, Vol. 37 No. 36, p. 40.

[13] Büttner, O. B., \& Göritz, A. S. (2008). Perceived trustworthiness of online shops. Journal of Consumer Behaviour: An International Research Review, 7(1), 35-50.

[14] Chaturvedi, D., Gupta, D., \& Singh Hada, D. (2016). Perceived risk, trust and information seeking behavior as antecedents of online apparel buying behavior in India: an exploratory study in context of Rajasthan. Sachin and Singh Hada, Devendra, Perceived Risk, Trust and Information Seeking Behavior as Antecedents of Online Apparel Buying Behavior in India: An Exploratory Study in Context of Rajasthan.

[15] Chaudhuri, A., \& Holbrook, M. B. (2001). The chain of effects from brand trust and brand affect to brand performance: the role of brand loyalty. Journal of marketing, 65(2), 81-93.

[16] Chen, Q., Zhang, M., \& Zhao, X. (2017). Analysing customer behaviour in mobile app usage. Industrial Management \& Data Systems.

[17] Cole, D. A. (1987). Utility of confirmatory factor analysis in test validation research. Journal of consulting and clinical psychology, 55(4), 584.

[18] Coulter, K. S., Brengman, M., \& Karimov, F. P. (2012). The effect of web communities on consumers' initial trust in B2C e-commerce websites. Management Research Review.

[19] Cowcher, R. (2001), "E-trust", The British Journal of Administrative Management, No. 28, pp. 22-3,

[20] Cox, Donald F., and Stuart U. Rich. "Perceived risk and consumer decision-making - the case of telephone shopping." Journal of marketing research 1, no. 4 (1964): 32-39.

[21] Culnan, M. J. (2000). Protecting privacy online: Is self-regulation working?. Journal of Public Policy \& Marketing, 19(1), 20-26.

[22] D'Alessandro, S., Girardi, A., \& Tiangsoongnern, L. (2012). Perceived risk and trust as antecedents of online purchasing behavior in the USA gemstone industry. Asia pacific journal of marketing and logistics.

[23] Dillon, T. W., \& Reif, H. L. (2004). Factors Influencing Consumers' E-Commerce Commodity Purchases. Information Technology, Learning \& Performance Journal, 22(2).

[24] Dogbe, C. S. K., Zakari, M., \& Pesse-Kuma, A. G. (2019). Perceived Online Risk, Consumer Trust and M-Shopping Behaviour. e-Journal of Social \& Behavioural Research in Business, 10(1), 10-23.

[25] Doney, P. M., \& Cannon, J. P. (1997). An examination of the nature of trust in buyer-seller relationships. Journal of marketing, 61(2), 35-51. 
[26] Doolin, B., Dillon, S., Thompson, F., \& Corner, J. L. (2005). Perceived risk, the Internet shopping experience and online purchasing behavior: A New Zealand perspective. Journal of Global Information Management (JGIM), 13(2), 66-88.

[27] Drennan, J., Sullivan, G., \& Previte, J. (2006). Privacy, risk perception, and expert online behavior: An exploratory study of household end users. Journal of Organizational and End User Computing (JOEUC), 18(1), 1-22.

[28] Dwyer, F. R., \& LaGace, R. R. (1986, August). On the nature and role of buyer-seller trust. In AMA summer educators conference proceedings (Vol. 11, pp. 40-45). Chicago: American Marketing Association.

[29] Eastlick, M. A., Lotz, S. L., \& Warrington, P. (2006). Understanding online B-to-C relationships: An integrated model of privacy concerns, trust, and commitment. Journal of business research, 59(8), 877-886.

[30] El-Ansary, O., \& Roushdy, A. (2013). Factors Affecting Egyptian Consumers' Intentions for Accepting Online Shopping. El-Ansary, Osama and Samir, Ahmed,(2013), Factors Affecting Egyptian Consumers' Intentions for Accepting Online Shopping, The Journal of American Academy of Business, Cambridge, 191-201.

[31] Farid, A. F. (2015). A study on the growing popularity and purchase of fashion product from online stores in India. International journal of research in engineering and technology, 8(4), 362.

[32] Fastoso, F., Whitelock, J., Bianchi, C., \& Andrews, L. (2012). Risk, trust, and consumer online purchasing behaviour: a Chilean perspective. International Marketing Review.

[33] Featherman, M. S., Miyazaki, A. D., \& Sprott, D. E. (2010). Reducing online privacy risk to facilitate e-service adoption: the influence of perceived ease of use and corporate credibility. Journal of Services Marketing.

[34] FTC (2000), Privacy Online: Fair Information Practices in the Electronic Marketplace: Report to Congress, Federal Trade Commission, Washington, DC.

[35] Gao, T., Wang, Y., Sirgy, M. J., \& Bird, M. M. (2002). An integrative model on the antecedents of buyer decision-making uncertainty in organizational purchasing. ACR Asia-Pacific Advances.

[36] Gaskin, J., James, M., \& Lim, J. Master Validity Tool. AMOS Plugin In: Gaskination's StatWiki, 2019.

[37] Gefen, D. (2000). E-commerce: the role of familiarity and trust. Omega, 28(6), 725-737.

[38] Grabner-Kräuter, S., \& Kaluscha, E. A. (2003). Empirical research in on-line trust: a review and critical assessment. International journal of human-computer studies, 58(6), 783-812.

[39] Ha, H. Y. (2004). Factors affecting online relationships and impacts. The Marketing Review, 4(2), 189-209.

[40] Ha, H., \& Coghill, K. (2008). Online shoppers in Australia: dealing with problems. International Journal of Consumer Studies, 32(1), 5-17.

[41] Ha, S., \& Stoel, L. (2009). Consumer e-shopping acceptance: Antecedents in a technology acceptance model. Journal of business research, 62(5), 565-571.

[42] Halimi, A. B., Chavosh, A., Choshalyc, S. H., Esferjani, P. S., \& Doghezlou, A. (2011, March). Factors affecting consumers' attitude towards online purchasing among degree holders in Singapore. In International Conference on Economics, Business and Marketing Management (EBMM 2011), Shanghai, China (pp. 118-122).

[43] Harridge-March, S. (2006). Can the building of trust overcome consumer perceived risk online?. Marketing intelligence \& planning. 
[44] Henseler, J., Ringle, C. M., \& Sarstedt, M. (2015). A new criterion for assessing discriminant validity in variance-based structural equation modeling. Journal of the academy of marketing science, 43(1), 115-135.

[45] Hu, L. T., \& Bentler, P. M. (1999). Cutoff criteria for fit indexes in covariance structure analysis: Conventional criteria versus new alternatives. Structural equation modeling: a multidisciplinary journal, 6(1), 1-55.

[46] Jacoby, J., \& Kaplan, L. B. (1972). The Components of Perceived Risk,(w:) Venkatesan M. In SV-Proceedings of the Third Annual Conference of the Association for Consumer Research.

[47] Jarvenpaa, S. L., \& Todd, P. A. (1996). Consumer reactions to electronic shopping on the World Wide Web. International Journal of electronic commerce, 1(2), 59-88.

[48] Jarvenpaa, S. L., Tractinsky, N., \& Saarinen, L. (1999). Consumer trust in an Internet store: A cross-cultural validation. Journal of Computer-Mediated Communication, 5(2), JCMC526.

[49] Johnson, D., \& Grayson, K. (2005). Cognitive and affective trust in service relationships. Journal of Business research, 58(4), 500-507.

[50] Kaplan, L. B., Szybillo, G. J., \& Jacoby, J. (1974). Components of perceived risk in product purchase: A cross-validation. Journal of applied Psychology, 59(3), 287.

[51] Kim, S. Y., \& Lim, Y. J. (2001). Consumers' perceived importance of and satisfaction with internet shopping. Electronic Markets, 11(3), 148-154.

[52] Koufaris, M., \& Hampton-Sosa, W. (2002). Customer trust online: examining the role of the experience with the Web-site. Department of Statistics and Computer Information Systems Working Paper Series, Zicklin School of Business, Baruch College, New York.

[53] Kramer, R. M. (1999). Trust and distrust in organizations: Emerging perspectives, enduring questions. Annual review of psychology, 50(1), 569-598.

[54] Kuhlmeier, D., \& Knight, G. (2005). Antecedents to internet-based purchasing: a multinational study. International Marketing Review.

[55] Kumar, D. (2017). Study on Trust \& Perceived Risk Regarding Online Shopping in Pune: A Factor Analysis. Study on Trust \& Perceived Risk Regarding Online Shopping in Pune: A Factor Analysis (October 8, 2017).

[56] Laroche, M., McDougall, G. H., Bergeron, J., \& Yang, Z. (2004). Exploring how intangibility affects perceived risk. Journal of Service research, 6(4), 373-389.

[57] Lee, M. K., \& Turban, E. (2001). A trust model for consumer internet shopping. International Journal of electronic commerce, 6(1), 75-91.

[58] Liebermann, Y., \& Stashevsky, S. (2002). Perceived risks as barriers to Internet and e-commerce usage. Qualitative Market Research: An International Journal.

[59] Lim, N. (2003). Consumers' perceived risk: sources versus consequences. Electronic commerce research and applications, 2(3), 216-228.

[60] Marsh, H. W., \& Hocevar, D. (1985). Application of confirmatory factor analysis to the study of self-concept: First-and higher order factor models and their invariance across groups. Psychological bulletin, 97(3), 562.

[61] Marsh, H. W., Balla, J. R., \& McDonald, R. P. (1988). Goodness-of-fit indexes in confirmatory factor analysis: The effect of sample size. Psychological bulletin, 103(3), 391.

[62] McCole, P., Ramsey, E., \& Williams, J. (2010). Trust considerations on attitudes towards online purchasing: The moderating effect of privacy and security concerns. Journal of Business Research, 63(9-10), 1018-1024.

[63] Mitchell, V. W., \& Vassos, V. (1998). Perceived risk and risk reduction in holiday purchases: A cross-cultural and gender analysis. Journal of Euromarketing, 6(3), 47-79. 
[64] Mitra, K., Reiss, M. C., \& Capella, L. M. (1999). An examination of perceived risk, information search and behavioral intentions in search, experience and credence services. Journal of Services Marketing.

[65] Miyazaki, A. D., \& Fernandez, A. (2000). Internet privacy and security: An examination of online retailer disclosures. Journal of Public Policy \& Marketing, 19(1), 54-61.

[66] MOHAMED, N., \& MOBASHERI, S. (2013). Perceptions of E-Marketing, Social Media, Individuals and Purchase Intention-What Can We Learn From Research?. In Mathematics and Computers in Contemporary Science Proceedings of the 14th WSEAS International Conference on Mathematical Methods and Computational Techniques in Electrical Engineering, Nanjing, China. p166-174.

[67] Morgan, R. M., \& Hunt, S. D. (1994). The commitment-trust theory of relationship marketing. Journal of marketing, 58(3), 20-38.

[68] Neskey, D. M., Osman, A. A., Ow, T. J., Katsonis, P., McDonald, T., Hicks, S. C., ... \& Lichtarge, O. (2015). Evolutionary action score of TP53 identifies high-risk mutations associated with decreased survival and increased distant metastases in head and neck cancer. Cancer research, 75(7), 1527-1536.

[69] Pappas, N. (2016). Marketing strategies, perceived risks, and consumer trust in online buying behaviour. Journal of retailing and consumer services, 29, 92-103.

[70] Park, C., \& Jun, J. K. (2003). A cross-cultural comparison of Internet buying behavior. International Marketing Review.

[71] Pavlou, P. A. (2003). Consumer acceptance of electronic commerce: Integrating trust and risk with the technology acceptance model. International journal of electronic commerce, 7(3), 101134.

[72] Peikari, H. R., Yasina, N. M., \& Shah, M. H. (2013). Determinants of online trust: a system oriented view. Am J Sci Res, 87, 25-45.

[73] Pires, G., Stanton, J., \& Eckford, A. (2004). Influences on the perceived risk of purchasing online. Journal of Consumer Behaviour: An International Research Review, 4(2), 118-131.

[74] Pope, N. K., Brown, M. R., \& Forrest, E. J. (1999). Risk, innovativeness, gender, and involvement factors affecting the intention to purchase sport product online. Sport Marketing Quarterly, 8(2), 25-34.

[75] Punyatoya, P. (2019). Effects of cognitive and affective trust on online customer behavior. Marketing Intelligence \& Planning.

[76] Roselius, T. (1971). Consumer rankings of risk reduction methods. Journal of marketing, 35(1), 56-61.

[77] Rotter, J. B. (1967). A new scale for the measurement of interpersonal trust. Journal of personality.

[78] Salo, J., \& Karjaluoto, H. (2007). A conceptual model of trust in the online environment. Online information review.

[79] Schiffman, L., O’Cass, A., Paladino, A., D’Alessandro, S. and Bednall, D. (2011), Consumer Behaviour, Pearson Education Australia, Sydney.

[80] Schlosser, A. E., White, T. B., \& Lloyd, S. M. (2006). Converting web site visitors into buyers: how web site investment increases consumer trusting beliefs and online purchase intentions. Journal of marketing, 70(2), 133-148.

[81] Sheth, J. N., \& Venkatesan, M. (1968). Risk-reduction processes in repetitive consumer behavior. Journal of Marketing research, 5(3), 307-310. 
[82] Shim, J. T., Van Slyke, C., Jiang, J. J., \& Johnson, R. D. (2004). Does trust reduce concern for information privacy in e-commerce. In Proceedings of the 7th Annual Conference of the Southern Association for Information Systems (Vol. 37, pp. 227-234).

[83] Sohaib, O., \& Kang, K. (2015). Individual level culture influence on online consumer iTrust aspects towards purchase intention across cultures: A SOR model. International Journal of Electronic Business, 12(2), 142-161.

[84] Szybillo, G. J., \& Jacoby, J. (1974). Intrinsic versus extrinsic cues as determinants of perceived product quality. Journal of Applied Psychology, 59(1), 74.

[85] Tan, F. B., \& Sutherland, P. (2004). Online consumer trust: a multi-dimensional model. Journal of Electronic Commerce in Organizations (JECO), 2(3), 40-58.

[86] Thompson, F. M., Tuzovic, S., \& Braun, C. (2019). Trustmarks: Strategies for exploiting their full potential in e-commerce. Business Horizons, 62(2), 237-247.

[87] Tsiames, I. S., \& Siomkos, G. J. (2003). E-Brands: The decisive factors in creating a winning brand in the net. Journal of Internet Marketing, 4(1).

[88] United Nations (2001), The Electronic Commerce and Development Report 2001, United Nations Conference on Trade and Development (UNCTAD), Geneva.

[89] United Nations (2005), Information Economy Report 2005, United Nations Conference on Trade and Development (UNCTAD), Geneva.

[90] van der Meulen, N. S. (2013). You've been warned: Consumer liability in Internet banking fraud. Computer law \& security review, 29(6), 713-718.

[91] Vijayasarathy, L. R., \& Jones, J. M. (2000). Print and Internet catalog shopping: assessing attitudes and intentions. Internet Research.

[92] Viklund, M. J. (2003). Trust and risk perception in western Europe: A cross-national study. Risk Analysis: An International Journal, 23(4), 727-738.

[93] Vos, A., Marinagi, C., Trivellas, P., Eberhagen, N., Skourlas, C., \& Giannakopoulos, G. (2014). Risk reduction strategies in online shopping: E-trust perspective. Procedia-Social and Behavioral Sciences, 147, 418-423.

[94] Walters, C. G. (1974). Consumer behaviour: Theory and practice. McGraw-Hill/Irwin. https://www.worldbank.org/en/country/ghana/overview (Accessed 12/11/18).

[95] World Bank (2018). Country Report. [Online] Available at:

[96] Wu, G., Hu, X., \& Wu, Y. (2010). Effects of perceived interactivity, perceived web assurance and disposition to trust on initial online trust. Journal of Computer-Mediated Communication, 16(1), 1-26.

[97] Yang, Z., \& Jun, M. (2002). Consumer perception of e-service quality: from internet purchaser and non-purchaser perspectives. Journal of Business strategies, 19(1), 19.

[98] Yeung, R. M., \& Morris, J. (2006). An empirical study of the impact of consumer perceived risk on purchase likelihood: a modelling approach. International Journal of Consumer Studies, 30(3), 294-305.

[99] Zhang, J., \& Nyiri, P. (2014). 'Walled'activism: transnational social movements and the politics of Chinese cyber-public space. International Development Planning Review, 36(1), 111-133. 